Naresh Kumar Agarwal

Simmons University, Boston, MA, USA

\author{
Yuan Ho Huang \\ Fu Jen Catholic University, New Taipei City, Taiwan
}

\author{
Sanda Erdelez \\ Simmons University, Boston, MA, USA
}

\title{
Aha! Librarians' predisposition for information encountering and serendipity in the workplace (Paper)
}

\begin{abstract}
:
It is not clear if people's high propensity for information encountering translates to organizational work settings. We investigate the relationship between individual predisposition for information encountering with the frequency of individual information encountering at work. Through a survey of 274 medical librarians of the top 100 medical schools, we found that individual information encountering was a significant predictor of information encountering at work. This finding helps information behavior researchers discover the transfer of behaviors from everyday-life to organizational environments. It brings attention to the need for greater support for information encounters at work, which may enhance their contribution to the organizational objectives.
\end{abstract}

\section{Background and Literature Review}

Information encountering (IE), coined by Erdelez (1997), refers to serendipity in information behavior and finding information by chance or accident when you are not looking for it, looking for some other information, or not looking at all, often leading to an 'aha!' moment (Erdelez, 1997; Agarwal, 2015; Erdelez \& Makri, 2020). Serendipity can help organizations be more creative and innovative (Cunha, 2010). Past studies on IE have looked at serendipity conceptually (Erdelez, 2005; Agarwal, 2015), in various information environments - physical (Björneborn, 2008) and digital (McCay-Peet \& Toms, 2017), learning (Giordano, 2010), different user groups such as historians (Buchanan \& Erdelez, 2019), journalists (Bird-Meyer, Erdelez, \& Bossaller, 2019), shoppers (Ocepek, 2017), and various other contexts of information behavior (Agarwal, 2018), but were not focused on how people experience IE in an organizational context. Ocepek (2018) argues that everyday includes work. Our research question is: Do the experiences of people who encounter information often (termed superencounterers - Erdelez, 1995) apply within the organizational work setting? Specifically, do librarians who are super-encounterers in their everyday life encounter information frequently within the library work setting? This research is part of a bigger study looking at the effect of organizational knowledge management (Huang, 2014; Agarwal \& Islam, 2014; Agarwal \& Islam, 2020) on the sharing and use of encountered information. 


\section{Research model and hypothesis}

Figure 1 shows our research model, including two variables and a hypothesis.

\begin{tabular}{|l|l|l|}
\hline $\begin{array}{l}\text { Individual predisposition for } \\
\text { information encountering } \\
\text { (Individual's IE score) }\end{array}$ & $\mathrm{H} 1 \quad \begin{array}{l}\text { Individual information } \\
\text { encountering in the } \\
\text { organization (Individual's } \\
\text { IE in organization) }\end{array}$ \\
\cline { 2 - 2 }
\end{tabular}

Figure 1. Research Model

Individual predisposition for information encountering (independent variable)

An important aspect of understanding IE relates to the characteristics of the people who experience this behavior. Erdelez (1995, p. 150) categorized people according to their perceptions of their IE experiences as: non-encounterers, occasional encounterers, encounterers, and super-encounterers. The super-encounterers are "serendipity-prone" (Merton, 1953), and rely on IE as an integral aspect of their information behavior. As we continue to learn about serendipity and IE experiences in various information environments and from various categories of information users, there is insufficient understanding of if and how these information behaviors transfer among different environments for the same categories of users. For example, do super-encounterers behave as such regardless of the information environment where they may find themselves? This question is especially interesting in terms of behaviors in everyday context and work context (Agarwal, 2018; Ocepek, 2018). In this paper, we operationalize individual predisposition for IE as the extent to which one is prone to encountering information by chance.

Individual information encountering within the organization (dependent variable) In this paper, we operationalize the individual IE within the organization in two ways agreement, based on the extent to which the study participants agree with a statement that they encounter information frequently at work, and with an additional frequency measure, where they specifically identify how often they encounter information within a day or a week. While there are no prior studies looking at the relationship between individual IE, and the IE of a same person in work situations, we posit that IE traits are likely to carry over to work environments, where a working person tends to spend a large amount of time. Therefore, we hypothesize:

H1: Individual predisposition for information encountering positively relates to the individual information encountering in the organization.

\section{Methodology}

We adopted the survey questionnaire method for gathering data for this study. The target population of the study is medical librarians. We chose a specific type of library to try and reduce difference among different library types, and for the ease of accessing a more 
homogeneous sampling frame. This sampling frame consisted of the medical librarians from the top 100 medical schools, as identified by the U.S. News 2021 Best Medical Schools (https://www.usnews.com/best-graduate-schools/top-medical-schools). The names and email addresses of 1,909 medical librarians from these top schools were collected from the publicly accessible websites between March and August, 2020.

\section{Instrument development}

The questionnaire items were developed from prior research studies. Nine items for the individual predisposition for information encountering (IE1-IE9) were adopted from Wise, Erdelez, \& Chiang (2012). For an individual's information encountering within the organization, we adapted two items - an agreement measure (IEO_AGREE) based on a 5-point Likert scale (strongly disagree/agree to encountering information very often at work), and a frequency measure based on encountering several times a day/week, etc. (IEO_FREQ). Both these items were adapted from Agarwal, Xu, \& Poo (2011), who investigated the source use by information seekers. See Table 1.

Table 1. Survey items to measure the constructs

\begin{tabular}{|l|l|l|}
\hline Variable & Code & Survey item \\
\hline $\begin{array}{l}\text { Individual } \\
\text { information } \\
\text { encountering in } \\
\text { the organization }\end{array}$ & IEO_AGREE & $\begin{array}{l}\text { 1. I serendipitously encounter information very often in the course of my } \\
\text { work within my organization (strongly disagree } 12345 \text { strongly agree) }\end{array}$ \\
\cline { 2 - 3 } $\begin{array}{l}\text { Individual } \\
\text { predisposition } \\
\text { for information } \\
\text { encountering }\end{array}$ & IE1 & $\begin{array}{l}\text { 2. I serendipitously encounter information (several times a day, about once } \\
\text { a day, several times a week, about once a week, about once in 2-3 weeks, } \\
\text { less than once in 2-3 weeks, don't encounter at all, other) }\end{array}$ \\
\cline { 2 - 3 } (IE_SCORE) & IE3 & $\begin{array}{l}\text { 1. When searching for information online, I scan things that aren't related } \\
\text { to what I'm looking for. }\end{array}$ \\
\cline { 2 - 3 } & IE4 & $\begin{array}{l}\text { 2. When searching for information online, I come across other information } \\
\text { that I wasn't looking for. }\end{array}$ \\
\cline { 2 - 3 } & IE5 & $\begin{array}{l}\text { 3. When I use search engines, I notice information I wasn't looking for. } \\
\text { 5. When I notice information that I wasn't looking for online, I tend to } \\
\text { interrupt my original search. }\end{array}$ \\
\cline { 2 - 3 } & IE6 & $\begin{array}{l}\text { 6. The process of finding information online gets interrupted by me } \\
\text { stopping to look at something unrelated to my original goal. }\end{array}$ \\
\cline { 2 - 3 } & IE7 & $\begin{array}{l}\text { 7. If a piece of online information catches my attention spontaneously, I } \\
\text { don't mind pursuing it even if it isn't related to my initial goal. }\end{array}$ \\
\cline { 2 - 3 } & IE8 & $\begin{array}{l}\text { 8. When I find unexpected information online that is interesting, I search } \\
\text { for more information on that topic. }\end{array}$ \\
\hline & IE9 & $\begin{array}{l}\text { 9. When I find unexpected information online that is interesting, I open a } \\
\text { new browser tab or a new window to explore the information further. }\end{array}$ \\
\hline
\end{tabular}

\section{Data collection and analysis}

The survey instrument (https://forms.gle/5zAvyychiY6xgTBb8) was pre-tested and the questionnaire approved by the Simmons University IRB. Individual emails were sent to 1,909 medical librarians, of which 1,870 were successfully delivered. The response rate was $14.65 \%$. (N=274). We used ANOVA, Regression, and the Chi-square test to analyze the data using PSPP 1.4.1, the open-source alternative to SPSS. 


\section{Findings}

We first present the demographics to understand the characteristics of our sample that we surveyed. Our sample reflects the library profession - majority self-identified as librarians with a master's degree, more women than men, diversity in age, and representing libraries in various regions of the United States (see Table 2 for more).

Table 2. Demographics (N=274)

\begin{tabular}{|c|c|}
\hline Gender & Man 76 (27.74\%); Woman 193 (70.44\%); Prefer not to say 5 (1.82\%) \\
\hline Age (years) & Min 26; Max 71; Mean 47.03; Median 47; Mode 39 \\
\hline Current job title/role & $\begin{array}{l}\text { Professional } 163(59.5 \%) \text {, Manager } 50 \text { (18.2\%), Director } 39 \text { (14.2\%), Assistant } 20 \\
(7.3 \%) \text {, not indicated } 2(0.7 \%)\end{array}$ \\
\hline $\begin{array}{l}\text { Current job area (one } \\
\text { participant can be in more } \\
\text { than one area) }\end{array}$ & $\begin{array}{l}\text { Libraries } 227 \text { (82.8\%), Technology } 18(6.6 \%) \text {, Archives } 14(5.1 \%) \text {, Academic } 14 \\
(5.1 \%) \text {, Administrative } 10(3.6 \%) \text {, Analytics } 4(1.5 \%) \text {, Marketing } 2(0.7 \%) \text {, Other } 2 \\
(0.7 \%) \text {, not indicated } 2(0.7 \%)\end{array}$ \\
\hline $\begin{array}{l}\text { Location (regions for } 50 \\
\text { states) }\end{array}$ & $\begin{array}{l}\text { Northeast ( } 7 \text { states) } 70(25.5 \%) \text {; Midwest ( } 8 \text { states) } 43(15.7 \%) \text {; South ( } 13 \text { states) } \\
100(36.5 \%) \text {; West ( } 9 \text { states) } 52(19 \%) \text {; states not mentioned (13 states) } 9(3.3 \%)\end{array}$ \\
\hline Time in field of work (years) & Min 0.5; Max 43; Mean 17.01; Median 15; Mode 10 \\
\hline Time in current job (years) & Min 0.25; Max 40; Mean 8.37; Median 5; Mode 2 \\
\hline Highest education & $\begin{array}{l}\text { Doctoral degree } 22(8 \%) \text {; Master's degree } 217 \text { (79.2\%); Bachelor's degree } 28 \\
(10.2 \%) \text {; Associate degree } 3(1.1 \%) \text {; some college / no degree } 2(0.7 \%) \text {; not } \\
\text { indicated } 2(0.7 \%)\end{array}$ \\
\hline $\begin{array}{l}\text { Specialization in highest } \\
\text { degree }\end{array}$ & $\begin{array}{l}\text { library and information science } 147 \text { (53.6\%); humanities (religion, philosophy, } \\
\text { english, classics, history, culture, writing, arts, music, film) } 25(9.1 \%) \text {; dual degree } \\
\text { with LIS } 15(5.5 \%) \text {; technology / business } 14 \text { (5.1\%); social sciences (psychology, } \\
\text { communication, anthropology) } 14(5.1 \%) \text {; science / engineering } 12 \text { (4.4\%); } \\
\text { education / instructional technology } 10(3.6 \%) \text {; archives } 8 \text { (2.9\%); health (not } \\
\text { including medical lib.) } 7 \text { (2.6\%); not indicated } 22(8 \%)\end{array}$ \\
\hline
\end{tabular}

\section{Analyzing difference between groups}

We found in our study that people encountered information serendipitously in different frequencies ranging from several times a day to once in less than 2-3 weeks (as measured by the code IEO_FREQ of the variable 'Individual information encountering in the organization'). Considering each frequency of encountering (e.g., several times a day) as a different group, we wanted to evaluate the effect of the individual's predisposition for information encountering (IE_SCORE) on each of these groups. This ANOVA result between different groups of 'individual's IE in organization' is presented in Table 3.

There was a significant effect of 'individual's IE score' at the $p<.001$ level among the different frequency groups $[\mathrm{F}(5,268)=5.32, \mathrm{p}<0.0001]$. Post hoc comparisons using the LSD test indicated that the individual's mean IE score for ' $\mathrm{a}$ ' - about once or less than once in 2-3 weeks $(\mathrm{M}=28.73, \mathrm{SD}=5.45)$ was significantly smaller than three other groups. Considering all post hoc comparisons (last column in the table), these results suggest that high IE scores of an 
individual correlate with high frequency of 'individual's IE in organization,' and that the more often people encounter information generally, the more likely they encounter more information at work.

Table 3. ANOVA result of 'individual's IE score' among different groups of 'individual's IE in organization'

\begin{tabular}{lrrrrl}
\hline Frequency groups (IEO_FREQ) & $\mathrm{N}$ & mean & std & F value & Post-hoc comparisons \\
\hline $\begin{array}{l}\text { a =about once or less than once in 2-3 } \\
\text { weeks }\end{array}$ & 36 & 28.73 & 5.449 & $5.32^{* *}$ & c $>\mathrm{a}, \mathrm{d}>\mathrm{a}, \mathrm{e}>\mathrm{a}, \mathrm{e}>\mathrm{b}, \mathrm{e}>\mathrm{c}$ \\
b=about once a week & 38 & 30.63 & 6.113 & & \\
C=several times a week & 85 & 32.15 & 5.699 & & \\
d=about once a day & 35 & 32.39 & 4.627 & \\
e=several times a day & 77 & 34.22 & 5.921 & \\
$\mathrm{f}=$ other-not sure & 3 & 30.33 & 3.055 & & \\
\hline
\end{tabular}

$* * \mathrm{p}<0.001$

Hypothesis testing

To test our hypothesis, we examined the relationship as presented in Figure 1.

When 'individual's IE in organization' (IEO_AGREE) was predicted, it was found that 'individual's IE score' (Beta $=0.343, \mathrm{p}<.001$ ) was a significant predictor. The overall model fit was R-squared $=0.118$ (adjusted R-squared 0.115 ). Thus, our hypothesis was supported. However, the low R-square value of less than $12 \%$ indicates that there are other factors that explain the individual's IE in organization beyond the individual's predisposition to information encountering.

Relationship between the two items of the 'Individual's IE in organization'

Finally, we also performed a chi-square test of independence to examine the relationship between the two dependent variables based on frequency (IEO_FREQ) and agreement (IEO_AGREE). The test was done to see if responses were consistent across these two measures. We re-coded these variables from 5 groups to 3 groups to meet the requirements of the statistical test. The cross table is shown in Table 4 . The results show that the relationship between these two variables is significant, $\chi 2(4, \mathrm{~N}=274)=51.871, \mathrm{p}<.00001)$. This means that irrespective of the measurement used, the respondents were consistent in indicating how often they encountered information within the organization.

Table 4. Cross table of IEO_AGREE and IEO_FREQ 


\begin{tabular}{|c|c|c|c|c|c|}
\hline & & \multicolumn{3}{|c|}{$\begin{array}{c}\text { IEO_AGREE } \\
\text { Likert Scale (I serendipitously encounter information } \\
\text { very often in the course of my work) }\end{array}$} & \multirow[b]{2}{*}{ Total } \\
\hline & & $\begin{array}{c}\text { Disagree \& Strongly } \\
\text { disagree }\end{array}$ & Neutral & $\begin{array}{c}\text { Agree \& } \\
\text { Strongly agree }\end{array}$ & \\
\hline \multirow{3}{*}{$\begin{array}{l}\text { IEO_FREQ } \\
\text { I } \\
\text { serendipitously } \\
\text { encounter } \\
\text { information }\end{array}$} & $\begin{array}{l}\text { About once or less } \\
\text { than once in } 2-3 \\
\text { weeks }\end{array}$ & $12(4.4 \%)$ & $15(5.5 \%)$ & $9(3.3 \%)$ & $36(13.1 \%)$ \\
\hline & $\begin{array}{l}\text { About once or several } \\
\text { times a week }\end{array}$ & $13(4.7 \%)$ & 37 (13.5\%) & $73(26.6 \%)$ & $\begin{array}{r}123 \\
(44.9 \%) \\
\end{array}$ \\
\hline & $\begin{array}{l}\text { About once or several } \\
\text { times a day }\end{array}$ & $3(1.1 \%)$ & $16(5.8 \%)$ & $96(35 \%)$ & $115(42 \%)$ \\
\hline Total & & $28(10.2 \%)$ & $68(24.8 \%)$ & $178(65 \%)$ & $274(100 \%)$ \\
\hline
\end{tabular}

\section{Discussion \& Conclusions}

In this study, we set out to answer the research question if the experiences of librarians who are predisposed to encountering information also apply at the organizational work setting. The findings of our study support the hypothesis that individual predisposition for IE positively relates to the frequency of individual information encountering in the organization. This suggests that IE behaviors translate from one environment to another. That is, both super-encounterers and non-encounterers (Erdelez, 1997) tend to carry on their encountering experiences from everyday context to their work environments. While informative, this transfer of IE practices from the general to specific work environments, on a conceptual level, is not surprising. This could indicate a healthy work culture in the libraries of the top 100 medical schools, where people have an environment where their individual IE behaviors are allowed to play out at work. However, there is also a possibility that a more nuanced operationalization of individual IE within organization would produce a more detailed and perhaps different results. From this study, we can conclude two things: 1) there are people who are predisposed to encountering information by chance, and recognizing when they do so - those who can be termed 'super-encounterers' (as found in previous studies e.g., Erdelez, 1995; Erdelez \& Makri, 2020); 2) these people are able to continue this trait/behavior in their organizational work setting as well. However, what still needs to be determined is what are the organizational implications of this transfer of IE to work situations. Does it, as the literature indicates, result in more creativity and innovation? Second, do organizations recognize the availability of the special information encountering skills provided by these super-encounterer employees? Third, what incentives and enabling mechanisms do organizations provide, if any, to create an environment where these super-encounterers can thrive further, and contribute to their best ability?

As our study shows, the individual's predisposition to IE is only one of the factors affecting the individual's IE in the library. A richer model with more independent variables is needed to investigate the other factors. As part of our larger study, we will investigate how various knowledge management practices in an organization may influence people's experiences of information encountering, from the perspective of encouraging IE, sharing encountered information, and so on. Future research might also look at the transfer of IE practices within forprofit organizations, as this study is limited to libraries, which are service-oriented, non-profit organizations. 


\section{References}

Agarwal, N. K. (2015). Towards a Definition of Serendipity in Information Behaviour. Information Research, 20(3), paper 675. http://informationr.net/ir/20-3/paper675.html

Agarwal, N. K., Xu, Y. (C.) \& Poo, D. C. C. (2011). A context-based investigation into source use by information seekers. Journal of the Association for Information Science and Technology, 62(6), 1087-1104. https://doi.org/10.1002/asi.21513

Agarwal, N. K. \& Islam, M. A. (2014). Knowledge management implementation in a library: Mapping tools and technologies to phases of the KM cycle. VINE: The Journal of Information and Knowledge Management Systems, 44(3), 322-344. https://doi.org/10.1108/VINE-01-20140002

Agarwal, N. K. \& Islam, M. A. (2020). Looking for Knowledge Management in Library and Information Science Research. Global Knowledge, Memory and Communication, 69 (8/9), 697716. https://doi.org/10.1108/GKMC-01-2020-0001

Agarwal, N. K. (2018). Exploring Context in Information Behavior: Seeker, situation, surroundings, and shared identities. In Synthesis Lectures on Information Concepts, Retrieval, and Services. San Rafael, CA: Morgan \& Claypool Publishers, 9(7), i-163. https://doi.org/10.2200/s00807ed1v01y201710icr061

Bird-Meyer, M., Erdelez, S., \& Bossaller, J. (2019). The role of serendipity in the story ideation process of print media journalists. Journal of Documentation, 75, 995-1012. https://doi.org/10.1108/JD-11-2018-0186

Björneborn, L. (2008). Serendipity dimensions and users' information behaviour in the physical library interface. Information Research, 13(4), 13-4.

Buchanan, S. \& Erdelez, S. (2019). Information encountering in the humanities: Embeddedness, temporality, and altruism. Proceedings of the Association for Information Science and Technology, 56(1), 32-42. https://doi.org/10.1002/pra2.58

Cunha, M. P. (2010). On serendipity and organizing. European Management Journal, 28(5), 319-330.

Erdelez, S. \& Makri, S. (2020). Information Encountering re-encountered: A conceptual reexamination of serendipity in the context of information acquisition. Journal of Documentation 76, 731-751. https://doi.org/10.1108/JD-08-2019-0151

Erdelez, S. (1995). Information encountering: An exploration beyond information seeking, unpublished $\mathrm{PhD}$ thesis, Syracuse University, Syracuse, NY.

Erdelez, S. (1997). Information encountering: a conceptual framework for accidental information discovery. In P. Vakkari, R. Savolainen, \& B. Dervin (Eds.). Proceedings of an international conference on Information seeking in context, Tampere, Finland, Taylor Graham, Los Angeles, CA, (pp. 412-421). 
Erdelez, S. (2004). Investigation of information encountering in the controlled research environment, Information Processing \& Management, 40(6), 1013-1025.

Giordano, P. J. (2010). Serendipity in teaching and learning: The importance of critical moments. Journal on Excellence in College Teaching, 21(3), 5-27.

Huang, Y. H. (2014). Measuring individual and organizational knowledge activities in academic libraries with multilevel analysis. The Journal of Academic Librarianship, 40(5), 436-446. https://doi.org/10.1016/j.acalib.2014.06.010

McCay-Peet, L. \& Toms, E. G. (2017). Researching serendipity in digital information environments. Synthesis Lectures on Information Concepts, Retrieval, and Services, 9(6), i-91.

McKenzie, P. J. (2003). A model of information practices in accounts of everyday-life information seeking. Journal of Documentation, 59(1), 19-40.

Merton, R. K. (1968). Social Theory and Social Structure. Free Press.

Ocepek, M.G. (2017). Passive information behaviors while grocery shopping. Proceedings of the annual meeting of the Association for Information Science and Technology, 54(1), 507-510.

Ocepek, M. G. (2018). Bringing out the everyday in everyday information behavior. Journal of documentation. 74(2), 398-411. https://doi.org/10.1108/JD-10-2016-0119

Wise, K., Erdelez, S., \& Chiang, Y.-H. (2012). Development of a scale to measure individual differences in opportunistic discovery of information. Paper presented at the International Communication Association Conference, May 24-28, Phoenix, AZ. 